\title{
HPLC evaluation of the minor lipid components of by-products resulting from edible oil processing
}

\author{
By Mohamed Hassan EL-Mallah*; Minar Mahmoud M.Hassanein and Safinaz Mohamed M. EL-Shami
}

\author{
National Research Center, Fats and Oils Dept., Dokki, Cairo, Egypt \\ E -mail: mohamedmallah504@ hotmail.com
}

\section{RESUMEN}

Evaluación por HPLC de componentes lipídicos minoritarios de subproductos de la refinación de aceites comestibles

El trabajo realiza una evaluación analítica de algunos subproductos resultantes del la refinación de aceites comestibles. Las muestras procedieron de 4 plantas que aplicaban refinación química. Después de un pretratamiento de las muestras estas se sometieron a un análisis cromatográfico para el aislamiento y derivatización de los siguientes componentes minoritarios: esteroles libres y acilados (FS y AS) y esterilglicosidos libres y acilados (FSG y ASG). Sin embargo, los tocoferoles se determinaron directamente a partir de las muestras pretratadas. Todos los componentes menores se analizaron mediante HPLC, utilizando detectores apropiados.

Algunos autores han estudiado los esteroles y los esteres de los esteroles en los subproductos de la refinación pero ninguno lo ha hecho hasta ahora con los glicosidos de los esteroles, que son son de gran importancia biológica.

Este estudio aporta información sobre subproductos enriquecidos con ciertos componentes que pueden ser una fuente interesante de los mismos. En el trabajo se discute asimismo el papel de las condiciones de refinación sobre la eliminación de dichos componentes de los aceites tratados. Se ha encontrado que los jabones contienen cantidades variables de tocoferoles que oscilan entre 80 y 230 ppm; la cantidad total de AS y FS osciló entre 240 a 4000 mg/100g mientras que la concentración total de FSG y ASG varió entre 1120 a 6375 $\mathrm{mg} / 100 \mathrm{~g}$. En caso de desodorización, los destilados contuvieron entre 960 to $7360 \mathrm{ppm}$ de tocoferol, mientras que el total de FS y AS se situó entre 1020 y $4160 \mathrm{mg} / 100 \mathrm{~g}$ y el de los totales de FSG y ASG entre 395 y 880 mg/100g.

PALABRAS-CLAVE: Análisis mediante HPLC - Esteroles acilados - Esteroles libres - Esterolglicosidos - Subproductos - Tocoferoles.

\section{SUMMARY}

HPLC evaluation of the minor lipid components of by-products resulting from edible oil processing

An analytical evaluation of some by-products resulting from edible oil refining processing steps has been carried out. By-product samples were taken from four different local refineries that apply chemical refining technology. Pretreatment of the representative samples of the by-products were done prior to analysis followed by chromatographic isolation and derivatization of the minor components, namely, free and acylated sterol (FS and AS) as well as free and acylated sterylglycosides (FSG and ASG). However, tocopherols were directly determined in the pretreated samples. HPLC, using different detectors, was carried out for the determination of these minor components.

Several authors have focused on the analysis of sterols and sterol esters, as well as tocopherols in the refining byproducts; however sterylglycosides, as biologically important components, have not been dealt with.

This study throws light on the by - products enriched with certain minor components to be possibly utilized as sources for such components. Also, the role of the conditions of the refining steps followed in removing these valuable minor components from oils was discussed. It was found that soapstock samples contained various amounts of total tocopherols ranging from 80 to 230ppm; total FS and AS ranged from 240 to $4000 \mathrm{mg} / 100 \mathrm{~g}$ while total FSG and ASG ranged from 1120 to $6375 \mathrm{mg} / 100 \mathrm{~g}$. In the case of deodorization distillate samples total tocopherols ranged from 960 to 7360 ppm; total FS and AS ranged from 1020 to $4160 \mathrm{mg} / 100 \mathrm{~g}$ and total FSG, ASG ranged from 395 to $880 \mathrm{mg} / 100 \mathrm{~g}$.

KEY-WORDS: Acylated sterols - By-products - Free sterols - HPLC - analysis - Sterylglycosides - Tocopherol.

\section{INTRODUCTION}

The influence of the vegetable oil refining process on minor components has been studied extensively (Carlson, 1996; Hodgasn, 1996; Hoffmann, 1989; Johnson, 1998). There are marked effects of process parameters during neutralization and deodorization on the reduction of the minor components in the refined oils (Gutfinger and Letan, 1974; Homberg and Bielefeld, 1982; Kanematsu et al., 1983; Jawad et al., 1984; Leon et al., 1984; Serani and Piacenti, 1992; Ferrari et al., 1996). During neutralization, a large part of phytosterols $(9-21 \%)$ is transferred by liquid - liquid partitioning to the soapstock (Gutfinger and Letan, 1974; Sciancalepore, 1981; Karaali, 1985 and Morchio et al 1987). The unsaponifiable fraction of soapstock contains an average $70 \%$ phytosterol (Morchio et al 1987). Sterylglycosides, as minor components, have attracted attention, due to their biological importance in reducing cholesterol and triglycerides in the liver and plasma of rats fed with these compounds (Murui et al., 1994). However no author, as far as one knows, has determined or dealt with sterylglycosides as valuable minor components present in refining by-products.

Soapstock, as an inexpensive liquid-rich byproduct, is seldom used today for recovery of fatty acids but it is often added to oilseed meal or can be disposed of with little economic compensation 
(Serani and Piacenti, 1992 and Kuk and Ballew, 1999). The conversion of plant sterols in oilseed soapstock via biocatalysts in order to yield pharmaceutical intermediates has been attempted (Kin et al., 1991). A compositional characterization of cottonseed soapstock has been carried out (Michael, 1996 and Verlyen et al., 2002) using GC analysis for determining sterols, free and esterfied and partial glycerides....etc. Deodorization is the last stage of refining and deodorization distillate (D.D) by-product contains FFA's that range between $30-50 \%$ for chemical and $80-90 \%$ for the physical refining of oils. In addition to FFA's the D.D contains some valuable minor components including tocopherols, tocotrienols, phytosterols, squalene, carotenoids etc. Depending on the refining conditions, tocopherol and phytosterol concentrations in D.D may vary from 2-20\% (Verlyen et al., 2001; Kaluka et al., 2004 and Buczenko et al., 2005).

Data from the literature on the influence of vegetable oil refining on free and esterified sterols and sterylglycosides as well as tocopherols are scarce and incomplete. Therefore, it was our objective to carry out a compositional study on the influence of the chemical refining process on the transfer of these minor constituents in soapstock and deodorization distillates. High sensitive HPLC methods of analysis, using different detectors, are necessarily used for determining the lipid components even when they are present in minute quantities. Most of the authors have dealt with the determination of sterols and tocopherols, however sterylglycosides have not been estimated in the refining by-product. Therefore, it was of interest to estimate tocopherols as well as free and acylated sterols and sterylglycosides in the soapstock and deodorization distillates obtained from different factories. This can give a clear picture, of the composition of the local by-products, produced annually in tons and as a guide for their possible utilization.

\section{MATERIALS}

The by-products arising from the processing of different edible oils (mainly soybean) were obtained from four different edible oils factories (in the 2004 season). The samples of the by-products used in this study were obtained from Extracted Oils (A), Salt and Soda (B), Sila (C) and Alexandria Oil and Soap (D) factories. From each factory, two by-products that belong to the same processing, namely, soapstock (neutralization step) and deodorization distillate were obtained. Each by -product did not arise from one oil type but was a mixture arising from the processing of at least two oils. One of them was major, which was soybean oil, subsequently processed in the same factory and according to processing schemes of these factories.

Standard tocopherols concentrate (80\%) containing alpha ,beta, gamma and delta tocopherol as well as standard anthroylnitrile derivatives of sterols were kindly supplied by Dr.
Tateo Murui (Nisshen Oil Mills, Research Lab., Yokohama, Japan).

\section{METHODS}

\section{By-Products Pre- treatments}

Prior to analyses of the minor components, namely, tocopherols, free and acylated sterols as well as sterylglycosides, it was necessary to carry out certain treatments for removing soaps and free fatty acids from the by-products to avoid any interference with the analyses of the minor components.

Soapstock samples (ca.5g) were extracted two times with $\mathrm{n}$-hexane and the organic phase was separated, filtered and washed until neutral and finally dried over anhydrous sod. sulphate. The filtered solvent was distilled off under reduced pressure at $50{ }^{\circ} \mathrm{C}$ in a rotary evaporator and the sample was kept in the refrigerator until it was used for analysis.

Similarly, samples of D.D were extracted twice with $\mathrm{n}$ - hexane and the hexane layer was titrated while stirring with dilute alcoholic $\mathrm{KOH}$ to remove the free acidity using an external indicator. The organic phase, separted by centrifugation, was washed thoroughly with water until neutral, and then dried over anhydrous sodium sulphate. The solvent was distilled off and the residue was subjected to analysis. The minor components, namely, tocopherols and sterols in treated soapstock and D.D were detected using TLC analysis. Hexane, ether, acetic acid solvent system (80/20/1 v/v/v) was used as developing solvent and the spots were visualized by $\mathrm{I}_{2}$ vapours (Mangold, 1965).

\section{HPLC Analysis}

\section{Tocopherols}

HPLC -fluorescence analysis of tocopherols (T) was carried out using a Toyo-Soda-CCPM HLC instrument. A sample of each treated by-product was dissolved in n-hexane to make $10 \%$ solution and $10 \mu \mathrm{l}$ was injected into the silica column (YMC-A-O12, $6.0 \times 150 \mathrm{~mm}$ ). Isocratic elution was conducted using n-hexane: isopropyl alcohol (100:0.5, by volume) as a mobile phase at a flow rate of 1 to $2 \mathrm{ml} / \mathrm{min}$. Hitachi$650-10 S$ fluorescence detector was used. Spectral absorption was set at excitation and emission wavelengths of 295 and $325 \mathrm{~nm}$, respectively.The conditions were optimized to elute delta-T after 10 $\mathrm{min}$. The results were automatically recorded as peak area percentage by an electronic integrator. From the peak area and the corresponding weight of each individual $\mathrm{T}$ in the standard and the sample, the total content in the oil (ppm) of tocopherols as well as the percentage composition was calculated (El-Mallah et al., 1994a). 


\section{Free and Acylated Sterols}

A samples $(100 \mathrm{mg})$ of pretreated by-product (soapstock and D.D) dissolved in chloroform was applied separately on silica gel G TLC plate $(300 \mu$ thickness).A solvent system of $n$-hexane: diethyl ether: acetic acid (70:30:1v/v/v) was used as the developing solvent. Cholesteryl oleate and cholesterol were used as standards with Rf values of 0.6 and 0.2 respectively; the zones were lightly stained with $\mathrm{I}_{2}$ vapor to locate free sterol and acylated sterol (Mangold, 1965). Each located zone was scraped off the plate and extracted with chloroform: methanol $1: 1 \mathrm{v} / \mathrm{v}$ and then centrifuged and the supernatant solution was removed by $\mathrm{N}_{2}$ stream .Only the AS fraction was deacylated via mild alkaline hydrolysis $(0.5 \mathrm{~N} \mathrm{KOH}$ in isopropyl alcohol). The obtained FS as well as the original FS were separately derivatized into 9- anthroylnitrile (SG-9-AN) (Wanaka and Murui, 1992). HPLC analysis was conducted under the following conditions: reversed phase column, ODS-1250Y, Senshu Pack (4.6x250mm); detector, fluorescence; excitation and emission wave lengths set at 360 and $460 \mathrm{~nm}$ and elution, isocratic using acetonitrile/ dichloromethane $(75 / 25, v / v)$ at a flow rate of $1 \mathrm{ml} / \mathrm{min}$. It is worth mentioning that this method is sensitive to 0.76-15 nanogram (Wanaka and Murui, 1992; El-Mallah et al., 1994a and 1999b).

\section{Free and acylated sterylglycosides}

The procedure of separation of free and acylated sterylglycosides from the treated byproducts, their derivatization into sterylglycosides 1- anthroylnitrile (SG-1-AN) ,HPLC analysis and the identification of the constituents were carried out according to Murui and Wanaka, 1993; El-Mallah et al., 1994a and 1999b.

The free sterylglycosides (FSG) and acylated sterylglycosides(ASG) were separated from the treated by-product by injecting the sample solution (100mg) into a silica gel cartridge (SepPak, Waters) and were eluted with chloroform: methanol $(1: 1 \mathrm{v} / \mathrm{v})$. The mixed compounds were subsequently divided into FSG and ASG with the help of a preparative TLC (Wako 70 plate). Chloroform/methanol /formic acid mixture (90/15/1, $\mathrm{v} / \mathrm{v} / \mathrm{v}$ ) was used as the developing solvent (ASG fraction has an Rf of 0.5 whereas the Rf of FSG is 0.3). The located zones were separately scraped of and extracted as mentioned before. Only the ASG fraction was subjected to alkaline hydrolysis $(0.5 \mathrm{~N}$ $\mathrm{KOH}$ in isopropanol) to obtain FSG. The original and obtained FSG were derivatized separately into SG-1-AN according to the same method mentioned above. An HPLC instrument equipped with a UV detector (Toso, UV 8000) and ODS Wakosil-5, $\mathrm{C}_{18}$ $(6.4 \mathrm{~mm} \times 250 \mathrm{~mm})$ was used for SG-1-AN analysis. Gradient elution with acetonitrile / dichloromethane (from 50/50 to $68 / 32 \mathrm{v} / \mathrm{v}$ ) was used and absorption was measured at $254 \mathrm{~nm}$. It is noteworthy that this method is sensitive to 0.5 nanogram of SG.

\section{RESULTS AND DISCUSSION}

\section{Minor constituents in soapstock}

Tables 1, 2 and 3 show concentrations and compositions of the different minor components, namely, tocopherols ,tocotrienols, free and acylated sterols and sterylglycosides respectively, the results can be discussed as follows:

\section{i. Tocopherols and tocotrienols}

With reference to tocopherols and tocotrienols in soapstock samples (Table1), it is indicated that the total tocopherols and tocotrienols ranges from 80 to $230 \mathrm{ppm}$. Sample A and D contain significantly higher total tocopherols whereas $B$ and $C$ samples contain comparatively lower total content (100 and $80 \mathrm{ppm}$ respectively). It is observed that the tocopherol profiles of samples $A, B$ and $D$ are rich in gamma and delta-tocopherols which can be similar to by-products arising from soybean oil (Minar, 1991) .Concerning the composition of soapstock sample $\mathrm{C}$ it is similar to soapstock produced from sunflower oil since it contains higher percentages of alpha- tocopherols but lower amounts of gamma- tocopherol $(\gamma)$. Compounds standing for tocotrienols in the soapstock samples are identified according to standard chromatograms (EL-Mallah and Murui, 1993) in spite of the fact that they are present in very minute quantities in crude or refined oils. Mainly gamma - and delta tocotrienols were detected in samples A and C.

Table 1

Tocopherols Composition in Soapstocks Produced from Different Factories

\begin{tabular}{|c|c|c|c|c|c|c|c|}
\hline \multirow{2}{*}{ Sample } & \multirow{2}{*}{$\begin{array}{l}\text { Total toc. } \\
\text { (ppm) }\end{array}$} & \multicolumn{6}{|c|}{ Tocopherol composition (\%) } \\
\hline & & $\alpha$ - toc. & $\beta$ - toc. & $\gamma$ - toc. & $\gamma-\mathrm{T} 3$ & $\delta$ - toc. & $\delta$ - T3 \\
\hline$A$ & 230 & 1.3 & 2.6 & 23.3 & 2.6 & 66.3 & 3.9 \\
\hline B & 100 & 1.5 & 2.4 & 24.7 & - & 71.4 & - \\
\hline C & 80 & 63.4 & 2.9 & 27.7 & 2.2 & 2.5 & 1.3 \\
\hline D & 200 & $\mathrm{Tr}$ & 4.0 & 64.4 & - & 32.0 & - \\
\hline
\end{tabular}

Toc.: Tocopherol; $\alpha$ - toc.: Alpha-tocopherol; $\beta$ - toc.: Beta- tocopherol; $\gamma$ - toc.: Gamma- tocopherol;: $\delta$ - toc.: Delta- tocopherol and T3: Tocoterinols 


\section{ii. Free and acylated sterols}

The HPLC analysis of free and acylated sterols is recorded in Table 2 showing the total weight of free and acylated sterols (isolated from soapstock via preparative TLC) as well as their patterns. Concerning the total weights of FS and AS in the samples, it can be seen that samples $A, B, C$ and $D$ contain 590, 240, 4000 and $890 \mathrm{mg} / 100 \mathrm{~g}$ oil respectively. It can be noted that sample $C$ is very rich in this type of sterols. It can also be noted that the FS fraction is the major fraction in the four samples.

The sterol patterns are elucidated with the help of an HPLC analysis of the 9-anthroylnitrile derivatives that showed the presence of avena, isofuco, brassica, spina, campe+ stigma (unseparable pair), 7-stigma and $\beta$-sitosterol. In addition, an unknown component appeared, however it stands for cholesterol. Brassicasterol, as a characteristic sterol for rapeseed oil (Minar, 1996), is found in the FS (3.6\%) and AS $(2.1 \%)$ of sample A, whereas it is detected in FS only in sample B. 7-Stigmasterol which is found in soybean, sunflower and cottonseed oils (Minar, 1996) was detected in comparatively higher amount in the AS of $A, C$ and $D$ samples ranging from 4.0 to $9.7 \%$ whereas it is present as FS in amounts ranging from 0.9 to $3.0 \%$. The major sterol in the FS and AS fractions of all samples is represented as $\beta$-sitosterol and ranges from 51.2 to $65.1 \%$ in the FS fraction whereas, from 53.7 to $63.2 \%$ in the AS fraction of the four soapstock samples. The campe+ stigmasterol (unseparable pair) is present in appreciable amounts in the four samples in both FS and AS fractions. It is found that campe+ stigmasterol is found at comparatively higher levels in the FS than the AS fraction.

Generally, processing conditions as well as the type of oils to be processed vary from one factory to another and therefore, the sterol composition showed different characteristic sterols.

\section{iii. Free and acylated sterylglycosides}

HPLC analysis of free and acylated sterylglycosides (FSG and ASG) as well as their contents (ppm) of the four soapstock samples are recorded in Table 3.

It can he seen that FSG is the major fraction in samples $B, C$ and $D$ whereas it is the minor fraction in sample A. HPLC analysis of sterylglycosides (SG's) as their 1-anlhroylnitrile derivatives shows the presence of avena, isofuco, campe+ stigma (unseparable pair), $\beta$-sito SG and an unknown sterol which can stand for cholesterol.

It can be noted that the major SGs determined in the four soapstock samples are campe+stigma $S G$ and $\beta$-sito SG, whereas avena - and the unknown SG are present as minor components, but isofuco $S G$ is present in reasonable amounts. It is worth mentioning that this HPLC method is very sensitive and more accurate to detect even minor constituents of SG such as their 1 - anthroylnitrile.

\section{Minor constituents in Deodorization Distillate (D.D)}

\section{i. Tocopherols}

HPLC analyses of tocopherols, total concentration and composition of the four deodorization distillate samples (D.D), are recorded in ( Table 4) The results show that a higher total tocopherols in sample $B$ amounting to $7360 \mathrm{ppm}$ was observed whereas, samples A, C and D contain 4630, 2680 and 960ppm respectively. These variations are due to processing conditions of D.D in each factory and the type of oil to be deodorized.

Table 2

Free and Acylated Sterols Composition in Soapstocks Produced from Different Factories

\begin{tabular}{|c|c|c|c|c|c|c|c|c|c|c|}
\hline \multirow[b]{2}{*}{ Sample } & \multirow{2}{*}{$\begin{array}{c}\text { State } \\
\text { of } \\
\text { sterol }\end{array}$} & \multirow{2}{*}{$\begin{array}{c}\text { Total } \\
\text { content } \\
\text { mg/100g }\end{array}$} & \multicolumn{8}{|c|}{ Free and acylated sterol composition (\%) } \\
\hline & & & $\begin{array}{c}\text { Avena } \\
\text { sterol }\end{array}$ & $\begin{array}{l}\text { Isofuco } \\
\text { sterol }\end{array}$ & $\begin{array}{c}\text { Brassica } \\
\text { sterol }\end{array}$ & $\begin{array}{c}\text { Unknown } \\
\text { sterol }\end{array}$ & $\begin{array}{l}\text { Spina } \\
\text { sterol }\end{array}$ & $\begin{array}{c}\text { Campe+ } \\
\text { Stigma } \\
\text { sterol }\end{array}$ & $\begin{array}{c}\text { 7- } \\
\text { Stigma } \\
\text { sterol }\end{array}$ & $\begin{array}{c}\text { B- } \\
\text { sito } \\
\text { sterol }\end{array}$ \\
\hline A & $\begin{array}{l}\text { FS } \\
\text { AS } \\
\text { Total }\end{array}$ & $\begin{array}{l}440 \\
150 \\
590\end{array}$ & $\overline{3.6}$ & $\begin{array}{l}0.9 \\
4.6\end{array}$ & $\begin{array}{l}3.6 \\
2.1\end{array}$ & $\begin{array}{l}0.5 \\
2.7\end{array}$ & $\overline{3.3}$ & $\begin{array}{l}37.2 \\
22.2\end{array}$ & $\begin{array}{l}0.9 \\
8.3\end{array}$ & $\begin{array}{l}56.9 \\
63.2\end{array}$ \\
\hline B & $\begin{array}{l}\text { FS } \\
\text { AS } \\
\text { Total }\end{array}$ & $\begin{array}{l}220 \\
020 \\
240\end{array}$ & $\frac{-}{-}$ & - & $\frac{0.3}{-}$ & $\begin{array}{c}1.8 \\
15.0\end{array}$ & - & $\begin{array}{l}32.8 \\
25.9\end{array}$ & - & $\begin{array}{l}65.1 \\
59.1\end{array}$ \\
\hline C & $\begin{array}{c}\text { FS } \\
\text { AS } \\
\text { Total }\end{array}$ & $\begin{array}{l}3500 \\
0500 \\
4000\end{array}$ & $\begin{array}{l}0.7 \\
0.9\end{array}$ & $\begin{array}{l}2.1 \\
3.5\end{array}$ & - & - & $\overline{0.2}$ & $\begin{array}{l}39.5 \\
37.2\end{array}$ & $\begin{array}{l}3.0 \\
4.0\end{array}$ & $\begin{array}{l}51.2 \\
53.7\end{array}$ \\
\hline D & $\begin{array}{c}\text { FS } \\
\text { AS } \\
\text { Total }\end{array}$ & $\begin{array}{l}860 \\
030 \\
890\end{array}$ & $\begin{array}{l}1.0 \\
4.2\end{array}$ & $\begin{array}{l}3.8 \\
3.3\end{array}$ & - & $\begin{array}{l}0.7 \\
5.8\end{array}$ & - & $\begin{array}{l}40.3 \\
16.6\end{array}$ & $\begin{array}{l}2.2 \\
9.7\end{array}$ & $\begin{array}{l}52.0 \\
60.4\end{array}$ \\
\hline
\end{tabular}

FS: Free sterol and AS: Acylated sterol 
Table 3

Free and Acylated Sterylglycosides Composition in Soapstocks Produced from Different Factories

\begin{tabular}{|c|c|c|c|c|c|c|c|}
\hline \multirow[t]{2}{*}{ Sample } & \multirow{2}{*}{$\begin{array}{l}\text { SG } \\
\text { Type }\end{array}$} & \multicolumn{6}{|c|}{ Free and acylated sterylglycosides composition (\%) } \\
\hline & & $\begin{array}{c}\text { Content } \\
\mathrm{mg} / 100 \mathrm{~g}\end{array}$ & $\begin{array}{c}\text { Avena } \\
\text { SG }\end{array}$ & $\begin{array}{c}\text { Isofuco } \\
\text { SG }\end{array}$ & $\begin{array}{c}\text { Unknown } \\
\text { SG }\end{array}$ & $\begin{array}{c}\text { Campe+ } \\
\text { Stigma SG }\end{array}$ & $\begin{array}{c}\text { B-Sito } \\
\text { SG }\end{array}$ \\
\hline \multirow[t]{3}{*}{ A } & FSG & 0054 & - & 3.2 & - & 35.8 & 61.0 \\
\hline & ASG & 4854 & - & 0.6 & - & 41.9 & 56.5 \\
\hline & Total & 4908 & & & & & \\
\hline \multirow[t]{3}{*}{ B } & FSG & 670 & 0.9 & 3.2 & - & 26.6 & 69.3 \\
\hline & ASG & 450 & 0.3 & 2.0 & - & 43.6 & 56.1 \\
\hline & Total & 1120 & & & & & \\
\hline \multirow[t]{3}{*}{ C } & FSG & 1189 & 0.7 & 4.8 & 0.8 & 13.2 & 80.5 \\
\hline & ASG & 1004 & - & - & - & 32.0 & 68.0 \\
\hline & Total & 2193 & & & & & \\
\hline \multirow[t]{3}{*}{ D } & FSG & 4278 & 0.5 & 2.0 & $\mathrm{Tr}$ & 36.6 & 60.9 \\
\hline & ASG & 2097 & - & - & - & 46.3 & 53.7 \\
\hline & Total & 6375 & & & & & \\
\hline
\end{tabular}

SG: sterylglycoside; FSG: Free sterylglycoside and ASG :Acylated sterylglycoside

Concerning the tocopherol composition of the four D.D samples, it was found that sample $A$ and $B$ are rich in gamma, and delta- tocopherols, whereas sample $\mathrm{C}$ and $\mathrm{D}$ contain higher amounts of delta- $\mathrm{T}$. These variations can be expected because the by-products are admixtures of two or more byproducts coming from different oils.

It is worth mentioning that the total content of tocopherols practically expresses the value of the D.D. to be utilized in the preparation of tocopherol concentrates. The four D.D. samples are considered as potential sources of tocopherols.

Soapstock samples (Table 1) contain lower amounts of total tocopherols than those present in corresponding D.D samples (Table 4). Therefore, D.D. ranks first as a potential source of tocopherols.

\section{ii. Free and acylated sterol}

Table 5 shows that markedly higher amounts of combined free and acylated sterols (FS and AS) are observed in samples B and C amounting to 2020 and $4160 \mathrm{mg} / 100 \mathrm{~g}$ respectively. However, samples $A$ and $D$ contain comparatively lower amounts of these sterols. HPLC analyses of FS and AS as their 9-anthroylnitrile derivatives show that campe + stigma sterol (unseparable pair) as well as $\beta$-sitosterol are predominating as FS and AS in the D.D samples.

Comparing these results with those obtained from the analysis of soapstock (Table 2), it can be observed that $\mathrm{C}$ sample of soapstock is rich in combined free and acylated sterols $(4000 \mathrm{mg} / 100 \mathrm{~g}$ ). Accordingly, sample $\mathrm{C}$ of soapstock as well as Band C samples of D.D can be feasible as potential sources for sterols.

\section{iii. Free and acylated sterylglycosides}

Table 6, shows the total contents of FSG and the ASG of D.D samples A, B, C and D as well as their composition as their 1-anthroylnitrile derivatives. It is observed that the total contents of FSG and ASG

Table 4

Tocopherols Composition in Deodorization Distillate Produced from Different Factories

\begin{tabular}{cccccc}
\hline \multirow{2}{*}{ Sample } & $\begin{array}{c}\text { Total } \\
\text { toc.(ppm) }\end{array}$ & \multicolumn{4}{c}{ Tocopherol composition (\%) } \\
\cline { 3 - 6 } & $\alpha$ - toc. & $\beta$ - toc. & $\gamma$ - toc. & $\delta$ - toc \\
\hline A & 4630 & 7.1 & 3.2 & 35.5 & 54.2 \\
B & 7360 & 12.1 & 1.9 & 54.6 & 31.4 \\
C & 2680 & 3.7 & 2.5 & 12.2 & 81.6 \\
D & 960 & 1.4 & 3.0 & 3.0 & 85.3 \\
\hline
\end{tabular}

Toc.: Tocopherol; $\alpha$-toc.: Alpha-tocopherol; $\beta$-toc.: Beta- tocopherol; $\gamma$-toc.: Gamma- tocopherol and: $\delta$-toc.: Delta- tocopherol 
Table 5

Free and Acylated Sterols Composition in Deodorization Distillate Produced from Different Factories

\begin{tabular}{ccccccccccc}
\hline Sample & $\begin{array}{c}\text { State } \\
\text { of } \\
\text { sterol }\end{array}$ & $\begin{array}{c}\text { Total } \\
\text { content } \\
\mathbf{m g} / \mathbf{1 0 0 g}\end{array}$ & $\begin{array}{c}\text { Avena } \\
\text { sterol }\end{array}$ & $\begin{array}{c}\text { Isofuco } \\
\text { sterol }\end{array}$ & $\begin{array}{c}\text { Brassica } \\
\text { sterol }\end{array}$ & $\begin{array}{c}\text { Unknown } \\
\text { sterol }\end{array}$ & $\begin{array}{c}\text { Spina } \\
\text { sterol }\end{array}$ & $\begin{array}{c}\text { Campe+ } \\
\text { Stigma } \\
\text { sterol }\end{array}$ & $\begin{array}{c}\text { 7- } \\
\text { Stigma } \\
\text { sterol }\end{array}$ & $\begin{array}{c}\text { B- } \\
\text { sito } \\
\text { sterol }\end{array}$ \\
\hline A & FS & 1220 & - & 2.6 & - & 0.5 & - & 44.8 & 0.8 & 51.3 \\
& AS & 0140 & 0.8 & 4.9 & - & 4.0 & - & 41.0 & 1.4 & 47.9 \\
& Total & 1360 & & & & & & & & \\
\hline B & FS & 1870 & - & 1.1 & 3.2 & 0.4 & - & 46.6 & - & 48.7 \\
& AS & 0150 & 1.9 & 3.5 & - & 6.3 & - & 39.4 & 2.4 & 46.5 \\
& Total & 2020 & - & & & & & & & \\
\hline C & FS & 3560 & 0.9 & 0.8 & - & 0.4 & 0.2 & 46.9 & 1.0 & 47.8 \\
& AS & 0600 & 0.7 & 3.1 & - & 3.7 & - & 4303 & 1.8 & 47.4 \\
& Total & 4160 & & & & & & & & \\
\hline D & FS & 880 & 0.8 & 3.3 & - & 0.6 & - & 46.2 & 0.8 & 48.3 \\
& AS & 140 & 1.6 & 3.6 & - & 3.2 & - & 43.7 & 1.3 & 47.2 \\
\hline
\end{tabular}

FS: Free sterol and AS: Acylated sterol

Table 6

Free and Acylated Sterylglycosides Composition in Deodorization Distillate Produced from Different Factories

\begin{tabular}{|c|c|c|c|c|c|c|c|}
\hline \multirow[t]{2}{*}{ Sample } & \multirow{2}{*}{$\begin{array}{c}\text { SG } \\
\text { Type }\end{array}$} & \multicolumn{6}{|c|}{ Free and acylated sterylglycosides composition (\%) } \\
\hline & & $\begin{array}{c}\text { Content } \\
\mathrm{mg} / 100 \mathrm{~g}\end{array}$ & $\begin{array}{c}\text { Avena } \\
\text { SG }\end{array}$ & $\begin{array}{c}\text { Isofuco } \\
\text { SG }\end{array}$ & $\begin{array}{c}\text { Unknown } \\
\text { SG }\end{array}$ & $\begin{array}{c}\text { Campe+ } \\
\text { Stigma SG }\end{array}$ & $\begin{array}{c}\text { B-Sito } \\
\text { SG }\end{array}$ \\
\hline A & $\begin{array}{l}\text { FSG } \\
\text { ASG } \\
\text { Total }\end{array}$ & $\begin{array}{l}030 \\
380 \\
410\end{array}$ & - & $\overline{0.2}$ & - & $\begin{array}{l}36.7 \\
41.2\end{array}$ & $\begin{array}{l}63.3 \\
58.6\end{array}$ \\
\hline B & $\begin{array}{l}\text { FSG } \\
\text { ASG } \\
\text { Total }\end{array}$ & $\begin{array}{l}580 \\
300 \\
880\end{array}$ & $\begin{array}{l}0.3 \\
1.5\end{array}$ & $\begin{array}{l}0.2 \\
0.1\end{array}$ & - & $\begin{array}{c}4502 \\
44.2\end{array}$ & $\begin{array}{l}55.3 \\
54.2\end{array}$ \\
\hline C & $\begin{array}{l}\text { FSG } \\
\text { ASG } \\
\text { Total }\end{array}$ & $\begin{array}{l}310 \\
430 \\
740\end{array}$ & $\begin{array}{l}0.5 \\
-\end{array}$ & $\begin{array}{l}3.2 \\
-\end{array}$ & $\underline{0.2}$ & $\begin{array}{l}15.1 \\
32.5\end{array}$ & $\begin{array}{l}81.0 \\
67.5\end{array}$ \\
\hline D & $\begin{array}{l}\text { FSG } \\
\text { ASG } \\
\text { Total }\end{array}$ & $\begin{array}{l}103 \\
292 \\
395\end{array}$ & $\begin{array}{l}0.3 \\
-\end{array}$ & $\frac{0.2}{-}$ & - & $\begin{array}{l}45.2 \\
46.0\end{array}$ & $\begin{array}{l}54.3 \\
54.0\end{array}$ \\
\hline
\end{tabular}

SG: sterylglycoside;FSG: Free sterylglycoside and ASG :Acylated sterylglycoside

are somewhat lower than expected and their contents range from 395 to $880 \mathrm{mg} / 100 \mathrm{~g}$.

It seems that sterylglycosides (SG) of $\beta$-sitosterol and campe + stigma are still predominating components in the SG present in D.D samples.

Comparing the total content of SG in soapstock (Table 3) with those present in D.D, it is clear that soapstock can be useful as a source for SG due to its higher total content of SG than in D.D.

\section{CONCLUSION}

In order to throw light on the potential of the byproducts studied in the present investigation as valuable sources of some specific minor components, it is advisable to categorize the by-products as follows:

1. Soapstock from factories $C$ and $D$ are rich in total FS and AS.

2. Soapstock from factories $A$ and $D$ are rich in sterylglycosides and tocopherols.

3. Deodorization distillates obtained from factories $B$ and $C$ are enriched with sterol lipids, namely, FS, AS, FSG and ASG.

4. Deodorization distillate samples obtained from factories $A$ and $B$ are rich in total tocopherols. 
Therefore, it can be concluded that these results reveal which by-product can be selected for its potential use as a source of certain lipid components. Meanwhile, it should be noted that tons of these byproducts are produced annually and sometimes cause pollution in the surrounding environment.

In addition, with the help of advanced HPLC methods of analysis, the minor lipid components were accurately determined to give a clear picture of the different lipid profiles in these by-products.

\section{REFERENCES}

Buczenko, M.G; De Oliveira ,S.J. and Von Meien, F.O 2005." Extraction of Tocopherol from The Deodorization Distillate Of Soybean Oil With Liquified Petroleum Gas ." European J. of Lipid Sci. and Techn. 105 (11) 668-671

Carlson, K.F., 1996."Deodorization, in Bailey's Industrial Oil and Fat Products, 4 Edible Oil and Fat Products: Processing Technology, edited by Y.D.Hui, John Wiley and sons. New York pp.339-390.

El-Mallah, M.H. and Murui, T. 1993."Local Food Industries By-Products Part 1, - Grape Seeds (Muskat), Wheat Germ and Deodorization Distillates of Cottonseed Oil." So Fw-J.119 Jahrgang 45 - 48.

El-Mallah, M.H.; Murui to and El-Shami,S. 1994a. " Detailed studies on Seed Oil of Salicornia Sos-7 Cultivated at the Egyptian Border of Red Sea. "Grasas Y Aceites, 45(6), $385-389$

El-Mallah, M.H.; Murui, T. and El-Shami, S.M. 1999b. "New Trends in Determining the Authenticity of Corn Oil." Grasas Y Aceites, 504, 7-15.

Ferrari, R.A.; Schulte, E.; Esteves, W.; Bruhl, L. and Mukherjee, K.D. 1996." Minor Constituents of Vegetable Oils During Industrial Processing." J. Am. Oil Chem. Soc.73, 587-592

Grob, K.; Artho, A. and Mariani, C. 1992." Determination of Raffination of Edible Oils and Fats by Olefinic Degradation Products of Sterols and Squalene, Using Coupled LC-GC." Fat Sci. Technol. 94, 394-399.

Gutfinger, T., and A. Letan. 1974. "Quantitative Changes in Some Unsaponifiable Components of Soybean Oil due to Refining." J.Sci. Food Agric. 25,1143-1147.

Hodgasn, A.S., 1996. "Refining and Bleaching." Bailey's Industrial Oil and Fat Products, 4 pp. 157-212.

Hoffmann, G., 1989 ."The Chemistry and Technology of Edible Oils and Fats and Their High Fat Products. Academic Press. New York. p. 384.

Homberg, E. and Bielefeld, B. 1982." Freie und Gebundene Sterine in Rohen und Raffinierten Palmolen. Teil 1: Gehalt und Zusammensetzung der Freien Sterine, Sterinester, Freien und Acylierten Steringlucoside." Fette Seifen Anstrichum 84, 141-146.

Jawad, I.M.; Kochhar, S.P.and Hudson, B.J.F. 1984. "The Physical Refining of Edible Oils 2-Effect on Unsaponifiable Components." Lebensm. Wiss. Technol. 17, 155-159.

Johnson, I.A., 1998. "Recovery, Refining, Converting, and Stabilizing Edible Fats and Oils, in Food Lipids, Chemistry, Nutrition, and Biotechnology, edited by C.C. Akoh.and D.B.,Min Marcel Dekker. New York, pp. 181-228.

Kaluka, N., M; Korczak, J; Wagner, H., K. and ELmadfa, I., 2004. "Tocopherol Composition of Deodorization Distillates and Their Antioxidative Activity." Nahrum Food 48 (1) 34-37
Kanematsu, H; Ushigusa, T; Maruyama, T; Nhya, I; Fumoto, D; Toyoda, T; Kawaguchi, Y and Matsumotm, T. 1983. "Comparison of Tocopherol Contents in Crude and refined Edible Vegetable Oils and Fats by High Performance Liquid Chromatography." Yukagaku 32(2) 122-127.

Karaali, A., 1985.”The Effects of Refining on the Chemical Composition of Turkish Sunflower Seed Oil. "Fette Seifen Anstrichm. 87,112-117

Kin,S.H.; S.H. Park and B.G.Ahn. 1991." Extraction and Determination of Phytosterols from Corn Oil Food." Aich. Pharm . Res.13,282-284

Kuk, M.S. and A.G-Ballew. 1999. "The Potential of Soapstock Derived Film: Cottonseed and Safflower." J.Am.Oil Chem.Soc. 76 (11) 1387 - 1392.

Leon, A.M; Liuzzi,V; La Notte, E. and Santoro, M. 1984." Steroli,Metilsterdlie Dimetilsteroli di alcuni Oli Vegetali con Particolare Riguardo a quelli di Oliva. Possibile Loro Ruolo Nella Caratterizzazione di alcuni Prodotti. Loro Variazione nel Processo di Rettifica." Riv. Ital. Sostanze Grasse 61: 69-89.

Mangold, H. K."Aliphatic Lipids"1965. in Thin- Layer Chromatography A Laboratory Handbook. Edited by Stahl, E., Academic Pressinc, Publishers, NewYork.

Michael K. Dowd. 1996. "Compositional Characterization of Cottonseed Soapstocks." J. Am. Oil Chem. Soc. 73(10)1287-1295

Minar Mahmoud, M.Hassanein. 1991. "Changes in the Content and Composition of Lipids During Maturation of Soybean and Sunflower Seeds." M.Sc. Degree, Cairo Egypt.

Minar Mahmoud, M.Hassanein."Studies on Biochemical Changes in Lipids of Some Maturing and Germinating Oil seeds. 1996 ." Ph.D. Degree, University of Ain Shams, Faculty of Science, Cairo,Egypt.

Morchio,G.; R.De Andreis, and E. Fedeli, 1987. "Indagine Sul Contenuto di Steroli Totali in Oil di oliva e sulle variazioni nel ciclo di raffinazione." Riv. Ital. Sostanze Grasse 64: 185-195.

Murui, T.and Wanaka, K. 1993. "Measurment of Sterglycosides by High Performance Liquid Chromatography with 1Anthroylnitrile Derivatives." Biosci. Biotech. Biochem., 57, 614-617.

Murui, T.; Yoshikawa M.; Takeuchi,H.; Fujii, S.; Mizobuchi, H. and Takenchi, H 1994." Effects of Sterylglycosides from Soybean on Lipid Indices in the Plasma, Liver and Feces of Rats." Biosci. Biotech. Biochem. 58 (3) 494-497

Sciancalepore, V., 1981. "The Influence of Processing on the Content and Composition of Free and Esterified Sterols in Sunflower Seed Oil." Oil Grassi Deriv. 17, 11-12

Serani, A., and D.Piacenti. 1992. "I Fenomeni chimicoFisici Che regolano La Perditadegli steroli Liberi durante la raffinazione degli oli vegetali." Riv. Ital. Sostanze Grasse 69, 311- 315

Verleyen, T; Verhe, R; Garcia, L; Dewettinck, K and Huyghebaert, A, De G. 2001." Gas Chromatographic Characterization of Vegetable Oil in Deodorization Distillate." J. Chromatogr. A 921 (2) 277-285

Verleyen,T.; U. Sosinska ; S.Joannidou ; R.Verhe ; K.Dewettinck; A.Huyghebaert and W.De Greyt. 2002." Influence of the Vegetable Oil Refining Process on Free and Esterified Sterols." J. Am. Oil Chem. Soc. 79 (10) $947-953$

Wanaka,K. and Murui, T. 1992."Determination of Sterols in Edible Oils and Fats by HPLC with Fluorescence Labeling." Yukagaku, 40, 306-311

Recibido: Julio 2005 Aceptado: Julio 2006 